\title{
THE SCOPE OF FINANCIAL LITERACY EDUCATION: A POVERTY ALLEVIATION TOOL IN SOCIAL WORK?
}

\section{Lambert Engelbrecht}

\section{INTRODUCTION}

The reference to financial literacy in the G8 Action Plan drafted at the Sea Island Summit 2004 (Cohen, Stach \& McGuinnes, 2004) is a demonstration of the growing awareness worldwide of the importance of promoting financial education, especially in developing countries. This has led to concepts such as financial literacy and financial education creating an interest in research especially by such institutions as banking companies, government agencies and community interest groups (Piprek, Dlamini \& Coetzee, 2004). These interest groups and institutions are generally concerned that their consumers lack basic knowledge of financial concepts and do not have the skills they need to make decisions advantageous to their economic well-being (Braunstein \& Welch, 2002). Financial literacy is thus globally increasingly viewed as an important requirement for successful functioning in a modern society. This trend suggests that educating people to become financially literate will gradually become even more important worldwide (Sandlant, Harris \& Barker, 2005), as people who are financially illiterate and therefore financially vulnerable, are increasingly excluded from the mainstream economy (INSOL International, 2001; Link, Vawser, Downes \& Chant, 2004; Noble, Ratcliffe \&Wright, 2004; Laderchi, Saith \& Stewart, 2006; Finmark Trust, 2007).

Interested parties generally accept that education is a much needed, although not definitive, tool to improve financial literacy of financially vulnerable people, thereby alleviating poverty (Jacob, Hudson \& Bush, 2000). However, while financial literacy on its own is not sufficient for the eradication of poverty, it plays an essential role. This role is to provide the means through which individuals can acquire the essential knowledge, skills and values to manage the money they possess, by building assets, managing debt and avoiding exploitation (Mavrinac \& Ping, 2004). Financial literacy education thus provides a way for migrating out of poverty. The success of such education programmes has been endorsed, especially recently by a multitude of empirically founded research studies (Garman, Kim, Kratzer, Brunson \& Joo, 1999; Heney, 2000; Jacob et al., 2000; Clancy, Grinstein-Weiss \& Schreiner, 2001; Braunstein \& Welch, 2002; Mavrinac \& Ping, 2004; Piprek et al., 2004; Bell \& Lerman, 2005; Friedman, 2005a; Nash, Jenkinson, Vayro \& Sandlant, 2005; Lusardi \& Mitchell, 2006).

The great number of research studies mentioned above is proof of the interest of society as a whole in providing financial education to its members, as the creation of a financially healthy civil society is to the benefit of both private and public institutions. A great variety of financial product-oriented programmes are therefore offered largely by financial institutions, but these programmes target credit facilities available to the financially viable segments of society and are mostly unsuccessful and unsuitable for low-income families and financially vulnerable people in general (Piprek et al., 2004; Goodwin-Groen \& Kelly-Louw, 2006).

Since financial literacy education is predominantly practised within the domain of financial institutions (Piprek et al., 2004), the question remains however, whether the social work profession could contribute to the financial literacy education of financially vulnerable people by facilitating this education as a poverty alleviation tool. In an attempt to address this question, this article aims to develop an understanding of the scope of financial literacy education in generalist social work intervention, by describing the rationale of such education, 
providing a definition of financial literacy, explaining the correlation between financial literacy education and poverty alleviation, and by examining the potential contribution of social work to financial education.

\section{RATIONALE OF FINANCIAL LITERACY EDUCATION}

Financial illiteracy has long been recognised as a major problem in poor households and communities. This is the result not only of inadequate access to, or inferior standards of, formal education, but also of insufficient access to information (Piprek et al., 2004). Empirical findings (Clancy et al., 2001; Finmark Trust, 2004; Lusardi \& Mitchell, 2006) show that quite a number of people in society are not capable of making even the most basic economic calculations, that their financial knowledge is generally too inadequate to save sensibly and to make other sound financial decisions, and that people with low levels of financial literacy also have low education and income. Qualitative studies (Fleetboston, 2003; Mavrinac \& Ping, 2004; Lusardi \& Mitchell, 2006) also indicated that most poor people themselves hold the view that their financial literacy is lacking, and that this contributes to their unfavourable circumstances. These indicators and authors such as Friedman (2005a) suggest that access to financial literacy programmes is a pressing need in societies, especially for people in transition from welfare to self-sufficiency.

Compared to people with a higher income, low-income workers and poor people in general often lack relevant information about how to gain access to mainstream banking and related opportunities, which impedes their ability to accumulate financial assets (Friedman, 2005b). Without an appreciation of fiscal concepts and an understanding of financial options, people are likely to pay more than they have to for financial services, fall into debt and over or under invest in financial products. People lacking the basic financial skills are also more vulnerable to sudden economic shocks (Jacob et al., 2000) such as health emergencies like HIV and Aids. For this reason money skills - implying some command over basics of budgeting, knowledge of savings vehicles and an understanding of credit and its terms - are as fundamental to life as reading (Mavrinac \& Ping, 2004).

Financial education is therefore an effective complement to traditional welfare, providing welfare recipients with knowledge, skills and values needed to make sound financial decisions, helping them participate in the mainstream financial system, to move up the economic ladder and eventually achieve financial security (Collins, 2007). Financial education could be a proactive and deliberate tool to link social grant beneficiaries and marginalised financially vulnerable people in general to opportunities for economic activity. Financial literacy is therefore not just a convenience, but a minimum requirement to ensure the optimal functioning of an individual in an increasingly complex society (Piprek et al., 2004). Financial literacy is thus an essential survival skill and indispensable to avoid being misled and exploited by the plethora of aggressively marketed financial products proffered by financial institutions (Jacob et al., 2000).

In summary, the rationale of financial literacy education is that it empowers people to exercise informed financial choices. Without an understanding of and control over financial resources, regardless how meagre they are, and without some sense that the financial future can be directed, people cannot exercise choice (Mavrinac \& Ping, 2004). 


\section{DEFINITION OF FINANCIAL LITERACY}

Being defined in the context of an ideology (Willis, 2008a), financial literacy is not an exact science, as it will always entail a level of judgment and discretion (Piprek et al., 2004). From a variety of research studies (Jacob et al., 2000; US Department of Labor, 2001; Finmark Trust 2004; Mavrinac \& Ping, 2004; Nash et al., 2005; Sandlant et al., 2005; Lusardi \& Mitchell, 2006), all of which formulate definitions of financial literacy education, it seems that financial literacy is a multi-dimensional concept related to, and overlapping with, several other concepts and disciplines. Such concepts as personal finance and family economics, money management, money knowledge, economic literacy and consumer literacy (Jacob et al., 2000; US Department of Labor, 2001; Goodwin-Groen \& Kelly-Louw, 2006) are used to refer, for example, to people's level of knowledge, skills and values in their dealings with monetary matters. Based on these concepts, people's literacy in respect of the economy, consumption, and finances amongst others, seems to determine their general level of vulnerability. This view is supported by a description provided by Jacob et al. (2000), of three interconnected categories, each contributing differently to an individual's ability to participate rewardingly in the economy.

The largest of the interconnected categories is economic literacy, which refers to general knowledge on how the economy functions. Economic literacy includes such concepts as scarcity, the interaction of supply and demand, inflation, price controls and international trade. The second category, consumer literacy, refers to the knowledge of rights and responsibilities needed to skilfully compare prices and make informed decisions about purchases. The third category, financial literacy, involves the ability to understand financial terms and concepts, and to translate the knowledge skilfully into behaviour. This embraces such concepts as savings, interests, budgeting, insurance and credit. Proficiency in dealing with financial service institutions is also included.

Of the three interconnected categories listed, people's financial literacy is the most critical for lower-income and poor families, as it principally and directly determines the amount of money they have available to spend. Financial literacy is therefore an indispensable set of skills (Jacob et al., 2000; US Department of Labor, 2001; Goodwin-Groen \& Kelly-Louw, 2006) that will define how money choices are made daily to ensure entrance into the financial mainstream, thereby contributing to self-sufficiency and ultimately financial well-being.

Should this set of skills be analysed in terms of the definitions by various authors of financial literacy (US Department of Labor, 2001; Cohen et al., 2004; Mavrinac \& Ping, 2004; Goodwin-Groen \& Kelly-Louw, 2006; Lusardi \& Mitchell, 2006), the following determinants of financial literacy could be identified: financial literacy means having the knowledge, skills, values and consequently, habits needed to successfully manage money at the personal and family level for earning, spending, saving, borrowing and investing. It enables people to make better financial choices, to work towards financial goals, to develop confidence, to become more aware of financial risks and opportunities, to plan realistically for the future, to respond competently to life events that affect everyday financial decisions, and to know where to go for help in financial matters and how to utilize it.

The definition of financial education generally adopted by the abovementioned researchers with a view to international consistency is that of Schagen (1997) in an evaluation report to the UK National Foundation for Educational Research (NFER). This definition could be considered as encompassing the abovementioned determinants and stipulates that financial 
literacy may be defined as the ability to make informed judgments and effective decisions regarding the use and management of money.

\section{THE CORRELATION BETWEEN FINANCIAL LITERACY EDUCATION AND POVERTY ALLEVIATION}

The correlations among poverty, financial literacy, general adult literacy, low skills levels, employment status, income and socio-economic status have been confirmed by numerous research studies undertaken throughout the world in recent years (Jacob et al., 2000; Bell \& Lerman, 2005; Sandlant et al., 2005). In order to explain these correlations, the implicit question of who are the poor (Noble et al., 2004), needs to be answered. Kakwani (2006) in accordance with Sen (1985), implies inter alia that individuals may be defined as poor if they lack basic capabilities. However, there is no clear-cut formula for determining basic capabilities because it is an issue of value judgment, depending on contexts and how a society prioritizes different capabilities based on the country's economic resources. In contrast with a traditional monetary perspective on human welfare, the enhancement of individuals' capabilities is needed to obtain optimal functioning in society, to succeed in life efforts, and to ultimately contribute to financial well-being.

Financial literacy as a fundamental capability (Mavrinac \& Ping, 2004) is illustrated by the International Labor Organization's (ILO, 2007) estimation that more people are underemployed or part of the "working poor" than people counted as officially unemployed worldwide. One of the reasons for this distinction between unemployed and underemployed is that globalization seems to have caused a shift in emphasis in the poverty struggle from simply having a job to having adequate income to live on. These "working poor" live mostly in developing countries, but there are also growing numbers of people working full-time in the so-called developed world, whose earnings do not push them over the poverty line of those countries (Davis, 2002). In this respect, research (Friedman, 2005b) has confirmed significantly that more families live in asset poverty than in income poverty. One explanation for asset poverty refers to a lack of knowledge about and access to traditional banking institutions. These people are referred to as the "unbanked" or the "underbanked" (Sandlant et al., 2005), and confirm the direct correlation between financial literacy and poverty in terms of financial exclusion.

Especially the following groups of people are "unbanked" or "underbanked": those with a lower education; those not working, for a number of reasons or who are in unskilled work; those with lower incomes; those with lower savings levels; single people; and people at both extremes of an age profile, consisting of younger and older people (Sandlant et al., 2005). These people are more exposed to overwhelming debts, insufficient savings and insufficient planning, and are more vulnerable to exploitative and fraudulent schemes (Piprek et al., 2004; Nash et al., 2005).

It is thus clear that there is more to leaving poverty than just finding a job. Besides receiving regular pay for regular work, a whole set of capabilities and skills is therefore necessary to make sound financial decisions, build savings and assets and establish good credit. For example, many welfare recipients entering the workforce for the first time, as well as lowincome workers at risk of depending upon public assistance, might lack these capabilities and skills (Rand, 2004). They are particularly at risk because they have little or no financial cushion for errors of judgment in the case of overspending, or to absorb economic emergencies or to recover thereafter (Jacob et al., 2000), such as a breadwinner falling ill with HIV and Aids (Piprek et al., 2004). For these people, good money management is a deliberate daily challenge 
(Cohen et al., 2004; Goodwin-Groen \& Kelly-Louw, 2006), which can be addressed by the contribution of social work to financial literacy education, in response to demands for poverty alleviation.

\section{THE POTENTIAL CONTRIBUTION OF SOCIAL WORK TO FINANCIAL LITERACY EDUCATION}

The contribution of social work to poor people's financial literacy education can be traced back to the beginnings of social work as expounded by Warner, Queen and Harper (1894) in the first edition of their book on American charities and social work, where the authors examined a number of conventional histories such as the Charity Organization Movement and the English poor law. The authors refer in the fourth edition of their book (Warner et al., 1930:25) to "changing approaches" in social work from 1893 to 1928 and elucidate specifically the "economic aspects of altruism". A humanitarian interest consequently made way for a professional approach to social work, “...making knowledge and skill available to persons who wish to use them rather than setting out to reform people regardless of their wishes in the matter" (Warner et al., 1930:25). This professional social work approach coincides with an earlier postulation of Byington (1910:74) concerning the skill to manage money for "homekeeping" as "... an asset which must be included in the family resources". In the same vain, Mary Richmond (1917:380) included the financial situation of families as an integrated part of social diagnoses and in doing so, paved the way for the contribution of social work to financial education of financially vulnerable people. It is thus evident that since its inception, social work has been particularly concerned with vulnerable people's financial matters. Similarly, the widespread and longstanding public support for financial literacy education is rooted in actions such as the foundation endowed by Alfred Sloan Jr., Chairman of General Motors Corporation in the 1930s, to create a "nation of economic literates" in the USA (Gordon, 1940:403).

Hence, as concerns about the financial matters of the poor increased globally throughout history, especially in the new millennium (United Nations, 2000), so too did the number and variety of financial education providers and programmes outside the social work domain, although various examples exist of the best practices delivered by social services in NGOs and CBOs (Jacob et al., 2000; Clancy et al., 2001; Braunstein \& Welch, 2002; Robinson, 2002; Piprek et al., 2004; Friedman, 2005a; Friedman, 2005b). While financial education by NGOs and CBOs is mainly directed towards poor and disenfranchised communities, other service providers of financial education usually do not necessarily possess the infrastructure to serve these communities. Also, service providers such as financial institutions are normally less interested in services to marginalised communities, as these communities do not present market expansion opportunities. NGOs and CBOs, on the other hand, are restricted in their outreach, as they might have limited general resources. This provides the opportunity for NGOs and CBOs to contribute to financial literacy education by forging partnerships with other significant providers of financial education to strengthen and improve their outreach (Jacob et al., 2000; Piprek et al., 2004).

The NGOs and CBOs normally extend their outreach to local residents in communities with which they are intimately familiar, as well as being conversant with the financial and educational needs of those community members. Local residents are also familiar with other programmes offered by these organisations and would have developed trusting relationships with them. The organisations concerned normally have at their disposal front-line staff who can communicate comfortably with community members to make concepts relevant and 
understandable, because they are sufficiently familiar with community members' cultural backgrounds (Jacob et al., 2000; Clancy et al., 2001; US Department of Labor, 2001; Piprek et al., 2004; Friedman, 2005a). In this way, community organisations (NGOs and CBOs) can for example act as bridge between the "unbanked" and traditional financial institutions by presenting relevant unbiased information in a context more familiar to community members (Friedman, 2005b). While other providers of financial education are focussing on broad-based financial literacy with the object of providing basic financial literacy to as wide an audience as possible, community organisations can facilitate financial literacy education programmes with a special focus on poverty alleviation, to vulnerable communities (Piprek et al., 2004).

Jacob et al. (2000) provided details of one such programme started by a community organisation managing a shelter for the homeless and rendering social services to recovering substance abusers. The shelter began offering a financial education programme to its clients, run by trained volunteers. The social service practitioners of the community organisation initiated the programme, because they discovered that as soon as clients acquired a permanent address or job, they were hounded by creditors from their past. This resulted in the clients running the risk of homelessness once again. The shelter's financial literacy education programme focused on basic banking skills because most of its clients never had a bank account.

The above example clearly illustrates that the intervention by the social service practitioners within the community organisation was focussed on the capabilities (Kakwani, 2006) of the clients because the enhancement of the homeless people's financial capabilities was regarded as fundamental to their optimum functioning in society, and in their life efforts to recover from alcohol abuse. This should ultimately contribute to their financial well-being (Mavrinac \& Ping, 2004) as well as to their welfare in general. The clients' existing capabilities served as basis for intervention, suggesting use of a strengths perspective (Saleeby, 2002) by the social service practitioners within the community organisation, as their focus would be directed towards those strengths of the clients which would enable them to make sound decisions regarding the use and management of money (Shagen, 1997). By focussing on the clients' strengths in the face of adversity (risking homelessness again), the intervention is in line with the contemporary paradigm of a strengths perspective in generalist social work practice (Miley, O'Melia \& Du Bois, 2001). The community organisation's utilization of volunteers as partners to enhance the financial and human well-being of vulnerable people is also in line with the paradigm suggested for social work to facilitate social development goals (Lombard \& Du Preez, 2003).

Consequently, the above example suggests the way in which social work within its professional domain could take ownership of and contribute to the financial literacy education of financially vulnerable people. This contribution of social work is based on the primary mission of enhancement of human well-being in accordance with the definition of the social work profession for the $21^{\text {st }}$ century (IASSW, 2001; IFSW, 2001). In this sense financial well-being, as described by Mavrinac and Ping (2004), is equivalent to human well-being, specifically where the latter constitutes "...a state of successful performance throughout the life course ...that results in productive activities" (Pollard \& Davidson, 2001:10).

A more explicit deduction thus arising from the preceding context is that social work activities (Hare, 2004:411-414) such as problem-solving (in respect of spending, saving, borrowing and investing), social change (to change habits needed to successfully manage money) and the empowerment and liberation of people (to exercise choice and create opportunities for 
understanding and control over financial resources), could contribute to the financial literacy of financially vulnerable people. These social work activities as indicated by Hare (2004) suggest that the holistic approach of social work to the person-in-environment and the systems theory (for example to view financial literacy in a multi-dimensional perspective as a set of skills and not as a one-size-fits-all effort) means that theories of human behaviour such as the personcentred theory (Hare, 2004:414), can be put to good use in the financial literacy education of vulnerable people, because financial literacy education employs amongst others a learnercentred approach (US Department of Labor, 2001; Cohen et al., 2004; Piprek et al., 2004) and thus coincides with the social work profession's "body of theory" (Hare, 2004:414).

Social work's theoretical foundation could thus conceivably instil financial literacy for good financial decision-making, mainly because financial literacy education without a sound theoretical base might not be sufficient and effective. According to Willis (2008b:3), biases and emotional coping mechanisms that interfere with welfare-enhancing personal financial behaviours, such as the avoidance of emotional discomfort during decision-making and responses to primary drivers such as hunger, which overwhelm reasoning, are unlikely to be eradicated through education alone. The research findings by the latter author indicate that only long-term and responsive financial education programmes, where educators analyse individual needs and provide customised intervention based on that assessment, might be effective. This perspective on financial education echoes those on social engineering (Willis, 2008b:54) and social change (Hare, 2004:409), implying an integration of financial education and social work with a dual focus on not only a change in people's skills, but also in their thought processes, feelings, motivations, and ultimately their values. In addition, contemporary scholars in the field of financial literacy education, such as Weiner and his colleagues (2005) support the development of financial education programmes that explicitly seek to change participants' attitudes or norms. This notion of integrating an interrelated system of values and theory in the practice of financial literacy education echoes the social work profession's methodology, based on a systematic body of evidence-based knowledge to analyse complex situations and to facilitate individual, organisational, social and cultural changes (Hare, 2004:419).

The preceding exploration serves as an example of how financial literacy education and primary social work activities could be integrated through the fulfilment of a facilitation role in generalist social work intervention. The fulfilment of a facilitation role (Terminology Committee for Social Work, 1995) constitutes expediting the process of social change, bringing together financially vulnerable people and financial education, stimulating relevant educational activities, developing and channelling of resources, and ensuring vulnerable people's access to expertise. It is within this scope that financial literacy education could be a tool in the facilitation of social change, where social change is defined as a "primary activity" (Hare, 2004:411) in social work.

As social work is a contextual, socially constructed profession with its activities defined by the social, economic and cultural realities in which it takes place, the profession must react to the needs and problems of the societal context of which it is a part. Needs and problems concerning people's limited choices are prevalent in most societies and are thus the primary focus of social workers (Taylor, 1999:310-312). This primary focus is similarly reflected in the rationale of financial literacy education, which is to empower people to exercise informed financial choices (Mavrinac \& Ping, 2004).

Furthermore, the growing importance of indigenous knowledge in social work, which suits economic and cultural realities (Hare, 2004:415), is also pertinent to financial literacy 
education, as familiarity with the culture, language and economical aetiology of the target system is a prerequisite for employing successful financial education (Jacob et al., 2000; Clancy et al., 2001; US Department of Labor, 2001; Cohen et al., 2004; Piprek et al., 2004; Friedman, 2005a). Consequently, as principles of human rights and social justice are fundamental to social work, on account of the profession's focus on the satisfaction of common human needs (Hare, 2004:416), social workers ought to demonstrate their understanding of the complex interaction among factors contributing to people's financial and social exclusion (Sandlant et al., 2005; Finmark Trust, 2007). However, social workers should show not only an understanding of financially excluded and consequently vulnerable people, but in the words of Hare (2004:417), should also broaden their conceptions in words and deeds about the profession's potential contributions to combine forces affecting societies' economic development. In this instance the broadening of social workers' conceptions requires an understanding of the scope of financial literacy education in generalist social work intervention and the potential contribution of this education as a poverty alleviation tool.

\section{CONCLUSION}

In an attempt to develop an understanding of the scope of financial literacy education, the question of whether the social work profession could contribute to the financial literacy education of financially vulnerable people was addressed in this article. From the answer it is clear that the rationale of financial literacy education is to empower people to exercise informed financial choices; that there is a definite correlation between financial literacy education and poverty alleviation; and that the potential contribution of social work to financial literacy education could be substantiated, based on the profession's theoretical foundation. Financial literacy education should be facilitated by social workers as a poverty alleviation tool with the primary mission of promoting social change in order to enhance the well-being of financially vulnerable people. Therefore, social workers should link financially vulnerable people and significant providers of financial education in the process of helping people coming out of poverty.

\section{REFERENCES}

BELL, E. \& LERMAN, R.I. 2005. Can financial literacy enhance asset building? Washington DC: The Urban Institute.

BRAUNSTEIN, S. \& WELCH, C. 2002. Financial literacy: An overview of practice, research, and policy. Federal Reserve Bulletin, November: 445-457.

BYInGTON, M.F. 1910. Homestead, the Households of a Mill Town. New York: Russel Sage Foundation Publication.

CLANCY, M., GRINSTEIN-WEISS, M. \& SCHREINER, M. 2001. Financial education and savings outcomes in individual development accounts. Center for Social Development, Working Paper 01-2. St. Louis: Washington University.

COHEN, M., STACH, K. \& McGUINNES, E. 2004. Financial education: a win-win for clients and MFIs. Washington DC: Microfinance Opportunities.

COLLINS, D. 2007. Focus note: Styles and profiles, investigating the financial lives of the poor. The connection between livelihoods and financial portfolios of the poor. Available: www.financialdiaries.com [Accessed: 28/04/2007]. 
DAVIS, S. 2002. Social entrepreneurship: Towards an entrepreneurial culture for social and economic development. Arlington: Ashoka.

FINMARK TRUST. 2004. Preliminary principles for expanding consumer financial literacy in SA. Marshalltown: FinMark Trust.

FINMARK TRUST. 2007. Access to savings products in the low income market. Johannesburg: South Africa Savings Institute.

FLEETBOSTON. 2003. Smarter decisions with Fleet National Survey, September 2003. Available: http://www.cbanet.org/SURVEYS/literacy/WEB\%20FINAL \%202004\%2Financial 1\%20 Literacy\%20Survey\%20Report.pdf [Accessed: 28/04/2007].

FRIEDMAN, P. 2005a. Providing and funding financial literacy programs for low-income adults and youth. Washington DC: The Finance Project.

FRIEDMAN, P. 2005b. Banking the unbanked. Helping low-income families build financial assets. Washington DC: The Finance Project.

GARMAN, E.T., KIM, J., KRATZER, C.Y., BRUNSON, B.H. \& JOO, S. 1999. Workplace financial education improves personal financial wellness. Columbus: Association for Financial Counseling and Planning Education.

GOODWIN-GROEN, R.P \& KELLY-LOUW, M. 2006. The National Credit Act and its regulations in the context of access to finance in South Africa. Marshalltown: FinMark Trust.

GORDON, L.L. 1940. Review: Next steps in consumer education, proceedings of a national conference on consumer education. Southern Economical Journal, 6(3):403-405.

HARE, I. 2004. Defining social work for the $21^{\text {st }}$ century. The International Federation of Social Workers' revised definition of social work. International Social Work, 3(47):406-424.

HENEY, J. 2000. Enhancing farmers' financial management skills. Agricultural Finance Revisited, 6:1-86.

INSOL INTERNATIONAL. 2001. Consumer debt report: Report of findings and recommendations. London: International Federation of Insolvency Professionals.

INTERNATIONAL ASSOCIATION OF SCHOOLS OF SOCIAL WORK (IASSW). 2001. Available: www.iassw-aiets.org [Accessed: 28/04/2007].

INTERNATIONAL FEDERATION OF SOCIAL WORKERS (IFSW). 2001. Available: WWW.ifsw.org [Accessed: 28/04/2007].

INTERNATIONAL LABOR ORGANIZATION (ILO). 2007. Available: www.ilo.org. [Accessed 28/04/2007].

JACOB, K., HUDSON, S. \& BUSH, M. 2000. Tools for survival: an analysis of financial literacy programs for lower-income families. Chicago: Woodstock Institute.

KAKWANI, N. 2006. Poverty and wellbeing. International Poverty Centre, UNPD, Poverty in focus, December: 20-21.

LADERCHI, C.E., SAITH, R. \& STEWART, F. 2006. Does the definition of poverty matter? Comparing four approaches. International Poverty Centre, UNPD, Poverty in focus, December: 10-11. 
LINK, P., VAWSER, S., DOWNES, S. \& CHANT, G. 2004. Summary presentation: research on financial exclusion in Australia. Victoria, Australia: ANZ, Chant Link \& Associates.

LOMBARD, A \& DU PREEZ, J. 2003. Overcoming the challenges of building partnerships in social development. Paper delivered at the social development conference, 5 June 2003. Stellenbosch: stellenbosch university.

LUSARDI, A. \& MITCHELL, O.S. 2006. Financial literacy and retirement preparedness: Evidence and implications for financial education programs. Michigan Retirement Research Center, Working Paper 2006-144. Michigan: University of Michigan.

MAVRINAC, S. \& PING, C.W. 2004. Financial education of women in Asia Pacific: An INSEAD working paper. Singapore: INSEAD Campus.

MILEY, K.K., O'MELIA, M. \& DU BOIS, B. 2001. Generalist social work practice. An empowering approach. Boston: Allyn and Bacon.

NASH, J., JENKINSON, A., VAYRO, A. \& SANDLANT, R. 2005. Understanding personal debt and financial difficulty in Australia. Melbourne: ANZ \& ACNielson.

NOBLE, M., RATClIFFE, A. \& WRIGHT, G. 2004. Conceptualizing, defining and measuring poverty in South Africa - An argument for a consensual approach. Centre for the Analysis of South African Social Policy (CASASP), Department of Social Policy and Social Work. Oxford: University of Oxford.

PIPREK, G., DLAMINI, P. \& COETZEE, G. 2004. Financial literacy scoping study and strategy project. Final report. Marshalltown: FinMark Trust, ECI Africa Consulting (Pty) Ltd.

POLLARD, E. \& DAVIDSON, L. 2001. Foundations of child well-being. Paris: UNESCO, Action Research in Family and Early Childhood.

RAND, D. 2004. Financial education and asset building programs for welfare recipients and low income workers: the Illinois experience. Washington DC: The Brookings Institution, Center on Urban and Metropolitan Policy.

RICHMOND, M.E. 1917. Social diagnosis. New York: Russel Sage Foundation.

ROBINSON, L. (ed) 2002. Guide to financial literacy resources. San Francisco: Federal Reserve Bank of San Francisco, Community Affairs Unit.

SALEEBY, D. 2002. The strengths perspective in social work practice $\left(3^{\text {rd }}\right.$ ed $)$. Boston: Allyn and Bacon.

SANDLANT, R., HARRIS, A. \& BARKER, N. 2005. AZN Survey of adult financial literacy in Australia. Melbourne: AZN \& ACNielson.

SCHAGEN, S. 1997. The evaluation of NatWest Face 2 Face With Finance. London: National Foundation for Education Research.

SEN, A.K. 1985. Commodities and capabilities. Oxford: Oxford University Press.

TAYLOR, Z. 1999. Values, theories and methods in social work education. A culturally transferable core? International Social Work, 42(3):309-318.

TERMINOLOGY COMMITTEE FOR SOCIAL WORK. 1995. New dictionary of social work. Cape Town: CTP Book Printers. 
UNITED NATIONS. 2000. United Nations Millennium Declaration. Resolution adopted by the General Assembly (A/55/L.2).

US DEPARTMENT OF LABOR. 2001. Dollars \& Sense: implementing financial education in a one-stop setting. Washington DC: Office of adult services, Division of welfare-to-work.

WARNER, A.G., QUEEN, S.A. \& HARPER, E.B. 1894 American charities and social work $\left(1^{\text {st }}\right.$ ed). New York: Thomas Y Crowell Company Publishers.

WARNER, A.G., QUEEN, S.A. \& HARPER, E.B. 1930. American charities and social work ( $4^{\text {th }}$ ed). New York: Thomas Y Crowell Company Publishers.

WEINER, L., BARON-DONOVAN, C., GROSS, K. \& BLOCK-LIEB, S. 2005. Debtor education, financial literacy, and pending bankruptcy legislation. Behavioral Sciences and the Law, 23:347-366.

WILLIS, E.L. 2008a. Evidence and ideology in assessing the effectiveness of financial Literacy education. Public law and legal theory research paper series. Research paper no. \#0808. Pennsylvania: University of Pennsylvania Law School.

WILLIS, E.L. 2008b. Against financial literacy education. Public law and legal theory research paper series. Research paper no. \#08-10. Pennsylvania: University of Pennsylvania Law School.

Dr Lambert K Engelbrecht, Senior Lecturer, Department of Social Work, University of Stellenbosch, South Africa. 